\title{
NON-GOVERNMENTAL ORGANIZATIONS AT THE WORLD TRADE ORGANIZATION: COOPERATION, COMPETITION, OR EXCLUSION
}

\author{
by Daniel C. Esty*
}

\section{INTRODUCTION}

Recent efforts by non-governmental organizations (NGOs), especially environmental groups, to participate in international trade policy-making activities have been met with hostility from the trade community. This article argues that this negative reaction is a mistake. Non-governmental organizations offer the World Trade Organization (WTO) a mechanism by which to 'connect' to citizens around the world in whose interest trade liberalization initiatives are advanced. Improved responsiveness and representativeness on the part of the WTO and better understanding of the international trading system on the part of the public would enhance the WTO's legitimacy and strengthen its position as a central element of the emerging structure of international economic governance. Non-governmental organizations offer, moreover, a source of analytic 'competition' to governments that promises to fortify the WTO's capacity to regulate in a manner that avoids market failures and to improve the organization's decision-making more generally, further augmenting the WTO's credibility and authoritativeness. The arguments for excluding NGOs from the WTO, particularly the fear that NGO participation in decision-making will result in special interest manipulation of outcomes, are largely misplaced.

\footnotetext{
* Yale Law School and Yale School of Forestry and Environmental Studies; formerly Deputy Chief of Staff and Deputy Assistant Administrator for Policy, Planning, and Evaluation at the US Environmental Protection Agency. Thanks to Judson Jaffe, Hari Osofsky, Raj Patel, Sonja Petersen, and Shalini Ramanathan for research assistance and to the Global Environment and Trade Study and its funders (Ford Foundation, MacArthur Foundation, Pew Charitable Trusts, Rockefeller Brothers Fund and Turner Foundation) and the Avina Foundation for support. Thanks as well to Bruce Ackerman, Frederick Abbott, Steve Charnovitz, André Dua, Jeffrey Dunoff, Phil Levy, William Nordhaus, Gus Ranis, William Rapp, William Rhoads, Susan Rose-Ackerman, Bruce Russett, Peter Spiro, Joel Trachtman, Thomas Weiss, and the participants in the Avina Foundation Workshop on Changing Roles of NGOs, the University of Michigan Conference on the Representation of Constituent Interests in US Trade Policymaking, and Yale International Political Economy Seminar for comments on earlier drafts.
} 
The magic of markets is now widely understood and appreciated. ${ }^{1}$ But markets sometimes fail, and when they do, governmental intervention is required to avoid allocative inefficiency and welfare losses. ${ }^{2}$ Markets fail for a number of reasons. Most notably, when externalities, such as unregulated pollution, exist, the 'invisible hand' cannot be counted upon to maximize social welfare. In addition, the well-known problems of 'free riding' and the 'tragedy of the commons' mean that market forces cannot be relied upon to generate optimal results with regard to the delivery of public goods or the management of open-access resources. ${ }^{3}$ In these cases, economic theory teaches that some sort of governmental intervention is required at a scale commensurate with the failure to be addressed, the public good to be provided, or the resource to be managed. ${ }^{4}$ In some circumstances, the scope of the problem will span several countries or even the entire world, making an international response at least optimal and sometimes essential.

From the greenhouse gas emissions that blanket the planet, to the need to protect biodiversity, to the unsustainable consumption of fish and other resources from the global commons, transboundary environmental problems frequently go unattended by national governments since no individual jurisdiction has an incentive to act. When national governments do attempt to regulate international market failures, however, disputes often erupt. American trade restrictions imposed on Mexican tuna caught using nets that killed large numbers of dolphins in the Eastern Tropical Pacific Ocean provide one such example. ${ }^{5}$ National government regulation to address domestic concerns also may have trade or other economic spillovers that become contentious. The European Union's restrictions on hormones in beef,

1 See Paul A. Samuelson and William D. Nordhaus, Economics 22, 43, 136 (15th edn, 1995); Robin Berman Schwartzman, Programs of the United States Government and Multinational Organizations Supporting Trade and Investment in Eastern Europe and the Former Soviet Union, 789 PLI/CORP. 497, 499 (1992); Kim Reisman, 'Note, The World Bank and the IMF: At the Forefront of World Transformation', 60 Fordham L Rev S349 at S349-51 (1992).

2 See William J. Baumol and Wallace E. Oates, The Theory of Environmental Policy (2nd edn, 1988) [hereinafter Baumol and Oates, Theory].

3 See Mancur Olson, The Logic of Collective Action: Public Goods and The Theory of Groups 28 (1965) [hereinafter Olson, Logic]; Garrett Hardin, 'The Tragedy of the Commons', 162 Science 1243, 1244-5 (1968); Carol Rose, 'The Comedy of the Commons: Custom, Commerce and Inherently Public Property', 53 U Chi L Rev 711 (1986); Gordon Tullock, 'Federalism: Problems of Scale', 6 Pub Choice 19 at 25-8 (1969).

4 See Baumol and Oates, Theory, above n. 2; Olson, Logic, above n. 3 at 48, 53-7; Daniel C. Esty, 'Stepping Up to the Global Environmental Challenge', 8 Fordham Env L Rev 103 at 105 (1996) (discussing the persistence of environmental threats 'because there is no international authority with the requisite breadth of authority to impose effective and equitable responses on the violators'); Richard B. Stewart, 'Pyramids of Sacrifice?: Problems of Federalism in Mandating State Implementation of National Environmental Policy', 86 Yale LJ 1196 at 1210-20 (1977) [hereinafter Stewart, Pyramids].

5 See Steve Charnovitz, 'Dolphins and Tuna: An Analysis of the Second GATT Panel Report', 24 Env L Rep 10 at 567 (1994). 
recently deemed inconsistent with international trade rules by a WTO dispute settlement panel, fit within this category. ${ }^{6}$

Into this regulatory breach has stepped the WTO. As the key global-scale institution with a mandate to manage the terms of international economic exchange and to set the behavioural boundaries for trade, the WTO cannot escape responsibility for helping to address market failures in its domain. In fact, the need for and value of a global regulatory structure is widely understood. ${ }^{7}$ But the WTO faces numerous tensions and difficulties in fulfilling its role as part of the international economic management structure and as the response mechanism to global-scale market failures.

Against the backdrop of these challenges, this article argues that the WTO will be able to carry out its economic management role better if it embraces $\mathrm{NGOs}^{8}$ and establishes formal procedures for NGO participation in the international trading system. ${ }^{9}$ Specifically, NGOs offer the promise of serving as 'connective tissue' that will help to bridge the gap between WTO

6 See 'Europe's Ban on Beef from US Held Illegal', New York Times, 2 July 1997, at D2.

7 See Jagdish Bhagwati and T.N. Srinivasan, 'Trade and Environment: Does Environmental Diversity Detract from the Case for Free Trade?' in Jagdish Bhagwati and Robert Hudec (eds), Fair Trade and Harmonization: Prerequisites For Free Trade? (1996) [hereinafter Bhagwati and Srinivasan, Trade and Environment]; Daniel C. Esty, 'The Case for a Global Environmental Organization' in Peter B. Kenen (ed.), Managing The World Economy: Fifty Years After Bretton Woods (1994) 287 [Hereinafter Esty, Geo]; Daniel C. Esty, 'Revitalizing Environmental Federalism', 95 Mich L Rev 57 at 613-53 (1996) [hereinafter Esty, Revitalizing ]; John H. Jackson, 'Reflections on Constitutional Changes to the Global Trading System', 72 Chi-Kent L Rev 511 at 512-15 (1996) [hereinafter Jackson, Reflections]; William D. Nordhaus, Locational Competition and the Environment, Discussion Paper No. 1079, at 5-8 Cowles Foundation for Research and Economics, Yale University (1994).

8 There is considerable debate over what groups should be considered 'non-governmental organizations'. Some observers would include only 'non-profit' entities such as environmental groups. Others would include all non-governmental entities including corporations. See Martin A. Olz, 'NonGovernmental Organizations in Regional Human Rights Systems', 28 Colum Hum Rts L Rev 307 at 313-21 (1997) (discussing the struggle to define NGOs). A further question arises as to whether to exclude non-profit business organizations such as the International Chamber of Commerce. See Steve Charnovitz, 'Two Centuries of Participation: NGOs and International Governance', 18 Mich J Int'l L 183 at 186-7 (1997) (defining the term NGO) [hereinafter Charnovitz, Two Centuries.] For the purposes of this article, I shall focus on all private (non-governmental) organizations that seek to shape decision-making at the national or international level with special reference to public interest groups such as environmental organizations.

9 The WTO has taken some steps to become more transparent and open to NGOs. In 1995, the WTO launched a worldwide web site (http://www.wto.org). In July 1996, the WTO released a set of 'Guidelines for Arrangements on Relationships with Non-Government Organizations' and made a renewed commitment to 'transparency', in part, in support of easier communications with NGOs. See General Council Decision on Ttransparency (18 July 1996). The WTO Committee on Trade and the Environment has held seminars to which environmental NGOs were invited. But all WTO General Council, Committee meetings and dispute settlement panel sessions remain closed to the public. Minutes of these meetings are not released. Non-governmental organizations have no right to make presentations or even submit written comments on issues under debate. Dispute panel decisions are not made public until the General Council adopts the decision. See Steve Charnovitz, 'Participation of Nongovernmental Organizations in the World Trade Organization', $17 \mathrm{U}$ Pa J Int'l Econ L 331 at 332-4 (1996) [hereinafter Charnovitz, Participation]. 
decision-makers ${ }^{10}$ and the distant constituents which they are meant to serve, thereby ensuring that the WTO's actions are perceived as responsive and fair. Non-governmental organizations also can act as 'competition' to governments in international trade debates. In doing so, they could broaden the base of information and thinking upon which decisions are made, and thus improve the quality, authoritativeness, and perceived fairness of the policy choices and judgments emanating from the WTO.

\section{CHALLENGES FACING THE WORLD TRADE ORGANIZATION}

The issues facing the WTO as it seeks to fulfill its role at the centre of the international economic system have been reviewed and discussed at length elsewhere. ${ }^{11}$ Fundamentally, the WTO must facilitate collective action among nations to support liberalized trade and investment and simultaneously overcome market failures which would otherwise disrupt the efficient workings and welfare-enhancing potential of the international marketplace. ${ }^{12}$ The WTO efforts in this respect involve negotiations to reduce tariffs and nontariff barriers to liberalized trade, the setting of trade rules to keep markets open, and the adjudication of disputes when differences arise.

In carrying out these functions, the WTO faces a number of critical challenges. First, in its adjudicatory role, the WTO needs to be recognized for its authoritativeness. ${ }^{13}$ The vitality of international organizations in general, and of the WTO in particular, depends on a capacity to produce 'correct' answers to the issues with which they must deal. ${ }^{14}$ In its core work involving trade liberalization and the settlement of traditional trade disputes, the WTO has an outstanding track record..$^{15}$ Over the past 50 years, the international trading system has developed a clear underlying theory,

${ }_{10}$ These decision-makers are fundamentally the national representatives at the WTO, but also should be understood to include the WTO staff who often shape the context of decisions.

11 See, e.g., Pitou van Dijck and Gerrit F. Faber, Challenges To The New World Trade Organization (1996) 1 at 24; Jeffrey J. Schott (ed.), The World Trading System: The Challenges Ahead (1996); Jackson, Reflections, above n. 7 at 519-20.

12 See Robert Gilpin, The Political Economy of International Relations 171 (1987); John H. Jackson, World Trade and The Law of GATT (1994) (discussing the operation of the international trading system) [hereinafter Jackson, Law of GATT]; John H. Jackson, The World Trading System: Law and Policy of International Economic Relations (1992) [hereinafter Jackson, World Trading]; Jackson, Reflections, above n. 7 at 512-15.

${ }^{13}$ For a discussion of the importance of authoritativeness, see W. Michael Reisman, 'Myres S. McDougal: Architect of a Jurisprudence for a Free Society’, 66 Miss LJ 15 at 20-1 (1996).

${ }^{14}$ See Jeffrey L. Dunoff, “"Trade And”: Recent Developments in Trade Policy and Scholarship-And Their Surprising Political Implications', 17 NW J Int'l L Bus 759 at 767 (1996-97) (arguing that poor WTO 'trade and environment' decisions could prompt a backlash against the WTO more broadly) [hereinafter Dunoff, Trade And]; see also Philip M. Nichols, 'Trade Without Values', 90 NW L Rev 658, 659-719 (1996).

15 See Robert Hudec, Enforcing International Trade Law (1995); E.U. Petersmann (ed.), International Trade Law and The GATT/WTO Dispute Settlement System (1997); Pierre Pescatore et al., Handbook of GATT Dispute Settlement (1996) (providing an overview of GATT dispute settlement). 
well-established rules, and a body of case experience to follow. ${ }^{16}$ The WTO has in-house staff and access to outside experts who are well-versed in all of these dimensions of support for the trading system and international economic law.

Yet increasingly, trade disputes involve issues at the intersection of trade and other policy arenas, such as the environment. ${ }^{17}$ In these cases, the WTO often lacks ready access to the necessary expertise for making well-regarded and broadly accepted decisions. Beyond the limited depth of the WTO's knowledge base, the organization's dispute settlement mechanisms lack credibility and legitimacy outside the realm of trade issues. In brief, the WTO faces serious questions about its capacity to deliver substantively correct decisions with respect to trade and environment disputes and to other conflicts arising on the periphery of trade law. ${ }^{18}$

In addition to substantive correctness, the WTO faces a further challenge of being, and of being perceived as, fair. Fairness has procedural and substantive requirements which must be met if WTO decisions, both in dispute settlement cases and in the negotiation of trade rules, are to have legitimacy. ${ }^{19}$ Procedurally, those who believe that they have an interest in the outcomes of decisions must have an opportunity to be part of the process, with opportunities to submit views and to observe how a particular outcome is reached. Substantively, the established rules and precedents must be applied even-handedly over time and across issues, and in ways that do not appear to advantage systematically any particular group or nation.

${ }^{16}$ See Jackson, Law of GATT, above n. 12; see also Philip M. Nichols, 'GATT Doctrine', 36 Va J Int'l Law 379 (1996). But note that by GATT tradition, past decisions are not meant to have precedential value. See WTO Report of the Appellate Body in Fapan-Taxes on Alcoholic Beverages, W1.1EL.-1-B-81, WT/DS 8FAB1R, WT/DS10/AB/R, WR/DS11/R (25 September 1996); Barry Eichengreen and Peter B. Kenen, 'Managing the World Economy Under the Bretton Woods System: An Overview', in Peter B. Kenen (ed.), Managing The World Economy: Fifty Years After Bretton Woods (1994) 3 (examining changes in the international system after World War II); Chi Carmody, 'Of Substantial Interest: Third Parties Under GATT', 18 Mich J Int'l L 615, 652-3 (1997).

${ }_{17}$ See, e.g., Jeffrey L. Dunoff, 'Institutional Misfits: The GATT, the ICJ and Trade-Environment Disputes', 15 Mich J Int'1 L 1043 (1994) (reviewing how ill-equipped the WTO is to handle such disputes) [hereinafter Dunoff, Misfits]; Dunoff, Trade And, above n. 14 at $762-4$ (discussing the WTO's 'expansion into new substantive areas'); GATT Report by Amb. H. Ukawa, Chairman, Group on Environmental Measures and International Trade, 49th Session of the Contracting Parties 3 (25 January 1994) (acknowledging that 'GATT is not equipped to become involved in the tasks of reviewing national environmental priorities, setting environmental standards, or developing global policies on the environment').

${ }_{18}$ Note that with no more in-house expertise than the WTO (and arguably less), the US Supreme Court renders 'trade and environment' opinions without stirring deep controversy of the sort that has sparked demonstrations against 'GATTzilla' in Washington. See Daniel C. Esty, Greening the GATT: Trade, Environment, and The Future (1994) 115 (questioning 'GATT's legitimacy, technical capacity, and neutrality in cases that involve environmental issues') [hereinafter Esty, Greening the GATT]; Dunoff, Misfits, above n. 17 at 1063-5 (arguing that the WTO is inescapably a 'trade' body and cannot therefore ever be seen as a fair broker); Dunoff, Trade And, above n. 14 at 763.

19 See Peter J. Spiro, 'New Global Communities: Nongovernmental Organizations in International Decisionmaking Institutions', 18 Wash Q 4 at 52-4 (1994) [hereinafter Spiro, Global Communities] (making the case for 'process legitimacy'). 
A third concern - the responsiveness and representativeness of those making the decisions - shapes impressions about the authoritativeness and fairness of the decision-making process. ${ }^{20}$ Whenever political choices derive from higher (more centralized) levels of government, which are inescapably more distant from the localized citizenry, issues of representation and fears of a 'democratic deficit' emerge. ${ }^{21}$ The trading system historically has been quite vulnerable on this point, facing regular attacks because of the perception that a secretive cabal of 'faceless international bureaucrats' in Geneva makes decisions without fully appreciating their impacts at the local level in countries around the world. ${ }^{22}$

Finally, the WTO faces a challenge of effectiveness. Because the organization has a small staff, it cannot hope to implement by itself the policy directions set in Geneva. The international trading system thus depends on others, particularly national governments, to carry out the decisions that it makes. In addition, the WTO has limited resources for oversight and auditing of its own performance or for forcing the compliance of national governments with internationally agreed goals. These limitations further constrict the WTO's capacity to shape trade policy and to implement it effectively. ${ }^{23}$

\section{NON-GOVERNMENTAL ORGANIZATIONS AT THE WORLD TRADE ORGANIZATION}

Non-governmental organizations can help the WTO to be more authoritative, fair, responsive, representative, and effective. Historically, NGOs have contributed to the efficacy and legitimacy of international organizations in a range of ways which should be instructive for the international trading system. ${ }^{24}$ Non-governmetnal organizations are currently part of the fabric of international decision-making in many realms outside of trade - again, with

${ }^{20}$ See Jackson, Reflections, above n. 7 at 517-18.

${ }^{21}$ See Naomi Roht-Arriaza, 'The Committee on Regions and the Role of Regional Governments in the European Union', 20 Hastings Int'l Comp L Rev 413 at 413-15 (1997) (discussing the 'simultaneous integration and decentralization' in the European Union context); Sol Picciotto, 'Networks in International Economic Integration: Fragmented States and the Dilemmas of Neo-Liberalism', 17 NW J Int'l L Bus 1014 at 1038 (1996-97) [hereinafter Picciotto, Networks] (describing democratic deficit problems in international institutions).

${ }^{22}$ See Esty, Greening the GATT, above n. 18 at 35-6 (reviewing these attacks); Ralph Nader, 'Free Trade and the Decline of Democracy' in Ralph Nader (ed.), The Case Against Free Trade: GATT, NAFTA, and The Globilization of World Power (1993); Walter Russell Mead, 'Bushism Found', Harper's 285 (September 1992).

${ }^{23}$ See Jackson, Reflections, above n. 7 at 517-18 (discussing WTO struggles with transparency and participation).

${ }^{24}$ See Hilary French, 'The Role of Non-State Actors' in Jacob Werksman (ed.) Greening International Institutions (1996) 251; Charnovitz, Two Centuries, above n. 8; Kal Raustiala, 'States, NGOs, and International Environmental Regimes', 41 Int'l Studies Q (1997); A. Dan Tarlock, 'The Role of Non-Governmental Organizations in the Development of International Environmental Law', 68 Chi-Kent L Rev 61 (1993) [hereinafter Tarlock, Role]. 
lessons applicable to the WTO. ${ }^{25}$ As I explain below, the participation of NGOs represents a crucial opportunity for the WTO in the organization's quest for strength and legitimacy. Yet, the recent entry of new types of NGOs, especially environmental groups, onto the trade stage has produced discomfort and even hostility within the trade community. ${ }^{26}$ The following sections examine the reasons for this response and review the various roles that NGOs might play at the WTO. Specifically, the case for NGOs as cooperators and competitors with governments at the WTO is advanced, and arguments for excluding NGOs from more active participation in international trade policy-making are reviewed.

\section{Non-governmental organization co-operation}

The potential for NGOs to play a co-operative role in assisting international decision processes is supported by a growing body of literature. Non-governmental organizations can serve as service providers (either acting independently or as government subcontractors); mobilizers of public opinion; defenders of view points that governments do not represent or under-represent; watchdogs or private enforcement agents; policy analysts and expert advisors to governments; and bridges between state and non-state actors connecting local and global politics. ${ }^{27}$

${ }^{25}$ See Thomas G. Weiss and Leon Gordenker (eds), NGOS, The UN, and Global Governance (1996) [hereinafter Global Governance]; Charnovitz, Two Centuries, above n. 8; Daniel C. Esty, 'Why the World Trade Organization Needs Environmental NGOs', 1 Public Participation in The International Trading System 11-15 (1996) [hereinafter Esty, Why NGOs]. But see Philip M. Nichols, 'Realism, Liberalism, Values, and the World Trade Organization', 17 U Pa J Int'l Econ L 851 at 856-60 (1996) (rejecting 'undisciplined comparison of international organizations') [hereinafter Nichols, Realism].

26 The 1994 agreement establishing the WTO allows for 'consultation and co-operation with nongovernmental organizations'. Final Act Embodying the Results of the Uruguay Round of Trade Negotiations, art. 5, \2, (15 April 1994), reprinted in 33 ILM 1125 at 1146 (1994). But little has been done to give form or content to this provision. See Charnovitz, Participation, above n. 9 at 332-4; Daniel C. Esty, 'Greening World Trade' in Jeffrey J. Schott (ed.), The World Trading System: Challenges Ahead (1996) 78-9 [hereinafter Esty, Greening Trade]; Esty, Why NGOs, above n. 25 at $3-4$.

${ }^{27}$ See Thomas Prince and Matthias Finger, Environmental NGOs in World Politics: Linking the Global and the Local (1994); A. Bebbington and J. Farrington, 'Governments, NGOs and Agricultural Development: Perspectives on Changing Inter-Organizational Relationships', 29 J Dev Stud 199 (1993); Charnovitz, Participation, above n. 9; P.O. Eikland, 'US Environmental NGOs: New Strategies for New Environmental Problems?', 19 J Soc Pol Econ Stud 259 (1994); Leon Gordenker and Thomas G. Weiss, 'Pluralizing Global Governance: Analytical Approaches and Dimensions' in Global Governance, above n. 25 [hereinafter Gordenker and Weiss, Pluralizing]; Philippe Sands, 'The Role of Environmental NGOs in International Environmental Law', 2 Dev J Soc Int'l Dev 28-32 (1996); Philippe Sands and Albert P. Bedecarre, 'Convention on International Trade in Endangered Species: The Role of Public Interest Non-Governmental Organizations in Ensuring the Effective Enforcement of the Ivory Ban', 17 BC Env Aff L Rev 799 (1990); Paul Wapner, 'Politics Beyond the State: Environmental Activism and Civil World Politics', 47 World Politics 311 (1995); S. Zadek and M. Gatword, 'Transforming the Transnational NGOs: Social Auditing or Bust?' in Michael Edwards and David Hulme (eds), Beyond the Magic Bullet: NGO 
In the WTO context, several of these roles are especially prominent. Notably, the WTO's reputation for responsiveness and representativeness as well as fairness will be shaped, in part, by its relationship with non-governmental bodies. As discussed above, one of the central tensions facing the WTO arises from concerns, as a matter of political theory, about decisionmaking in general that occurs at a great distance from the affected public and about the representativeness of WTO decision-making mechanisms in particular. Much stress is placed in the USA on federalism, with an emphasis on keeping political choices as close to the people as possible. ${ }^{28}$ Similarly, in the European Union, subsidiarity is a byword and a rallying cry for those who seek decentralized decision-making. ${ }^{29}$

Despite the preference for decentralized decision-making, in some circumstances, economic efficiency and the demands of effective governance require that policy-making occur at higher levels of authority. ${ }^{30}$ In particular, international regulation is necessary when salient externalities arise on a worldwide scale. ${ }^{31}$ That governmental intervention is both necessary and advisable in these circumstances, however, does not mean that it will happen. ${ }^{32}$

Unless governments are convinced to surrender a bit of sovereignty to make international collaboration possible, collective action will not occur, no

Performance and Accountability in the Post Cold War World (1996); Spiro, Global Communities, above n. 19; James Cameron and Ross Ramsay, Participation by Non-Governmental Organizations in the World Trade Organization, Global Environment and Trade, Study Working Paper No. 1 (New Haven) [hereinafter Cameron and Ramsay, Participation].

${ }^{28}$ See Esty, Revitalizing, above n. 7 at $605-13$ (reviewing the arguments for decentralized decisionmaking).

${ }^{29}$ See George A. Bermann, 'Taking Subsidiarity Seriously: Federalism in the European Community and the United States', 94 Colum L Rev 331 (1994); Denis J. Edwards, 'Fearing Federalism's Failure: Subsidiarity in the European Union', 44 Am J Comp L 537 (1996); Paul D. Marquardt, 'Subsidiarity and Sovereignty in the European Union', 18 Fordham Int'l LJ 616 (1994); Joel P. Trachtman, 'Etat C'est Nous: Sovereignty, Economic Integration and Subsidiarity', 33 Harv Int'l LJ 459 (1992); W. Gary Vause, 'The Subsidiarity Principle in European Union Law - American Federalism Compared', 27 Case W Res J Int'l L 61 (1995).

${ }^{30}$ See Esty, Revitalizing, above n. 7 at 613-52 (explaining when centralized decision-making, including international regulation, will sometimes be necessary); see also Stewart, Pyramids, above n. 4.

${ }^{31}$ See Andre Dua and Daniel C. Esty, Sustaining the Asia Pacific Miracle: Environmental Protection and Economic Intergration (1997) (arguing that economic integration inevitably requires non-economic integration to some degree - and thus some structure of international regulation); Robert Lawrence et al., A Vision For the World Economy: Openness, Diversity, and Cohesion (1996); Dani Rodrick, Has Globalization Gone Too Far (1997); Bhagwati and Srinivasan,Trade and Environment, above n. 7; Nordhaus, Locational Competition, above n. 7.

${ }^{32}$ Of course, political interventions may fail too, requiring comparative institutional analysis and a search for solutions that promise least failure. See Neil K. Komesar, Imperfect Alternatives: Choosing Institutions in Law, Economics, and Public Policy (1994) (explaining the need for comparative institutional analysis); Joel Trachtman, 'The Theory of the Firm and the Theory of the International Economic Organization: Toward Comparative Institutional Analysis', 17 NW J Int'1 Bus 470 (1996-97) (reviewing this theory in the context of international organizations); Dua and Esty, above n. 31 (discussing the range of market and regulatory failures). 
matter that the result is suboptimal regulation or even persistent market failure. Whether governments can be persuaded to co-operate through international organizations such as the WTO depends on these bodies being able to demonstrate a capacity to deliver collective action gains ${ }^{33}$ and a responsiveness and representativeness that protects the national governments from criticism by their domestic constituents about the ceding of decision-making to distant and unresponsive officials. ${ }^{34}$

The WTO's need for connectedness to people around the world creates a special opportunity for NGOs. In fact, while national representatives in Geneva officially represent their governments - and thus their publics-at the WTO, individuals for a variety of reasons may not feel adequately represented by their governments. First, states are imperfect representatives of public opinion. Governments systematically disregard minority viewpoints. As the public choice literature amply demonstrates, a position that is in the minority across many jurisdictions may, in fact, enjoy a plurality of support at a higher level of aggregation in voting. ${ }^{35}$ Permitting NGOs to participate in WTO discussions thus might allow the organization to hear important voices which would otherwise be unrepresented or under-represented in Geneva. $^{36}$

Second, many people today do not have their identities determined by the geographic political jurisdiction in which they happen to live. ${ }^{37}$ Non-governmental organizations cut across political boundaries and define 'communities of interest', uniting individuals who are committed to human rights, animal welfare, peace, or any number of other causes or view points. In doing so, they offer an alternative form of 'representation' that may, in some

33 Many analysts believe that governmental efforts to address market failures are likely to lead to worse rather than better results. See, e.g., Peter S. Menell, 'Institutional Fantasylands: From Scientific Management to Free Market Environmentalism', 15 Harv JL Pub Poly 489 (1992); Maxwell L. Stearns, 'The Misguided Renaissance of Social Choice', 103 Yale LJ 1219 at 1229 (1994).

${ }^{34}$ Indeed, whatever sovereignty is ceded will be reclaimed to the extent that emerging international institutions such as the WTO are perceived to serve alien interests. See Peter J. Spiro, 'New Global Potentates: Nongovernmental Organizations and the "Unregulated” Marketplace', 18 Cardozo L Rev 957 at 958 (1996) [hereinafter Spiro, Potentates]; see also Henry N. Butler and Jonathan R. Macey, 'Externalities and the Matching Principle: The Case for Reallocating Environmental Regulatory Authority', 14 Yale J Reg 23 at 25-9 (1996) (arguing for a more decentralized environmental governance structure).

35 See Herbert Hovenkamp, 'Legislation, Well-Being and Public Choice', 57 U Chi L Rev 63 at 75 (1990) (providing an example of this problem) [hereinafter Hovenkamp, Legislation.]

36 A number of today's global NGOs, from Amnesty International to the Worldwide Fund for Nature, clearly represent transnational interest groups that unite people across the globe who share common interests. See Paul Wapner, Environmental Activism and World Civic Politics (1995); see also, Wendy Schoener, 'Note, Nongovernmental Organizations and Global Activism: Legal and Informal Approaches', 4 Ind J Global Legal Stud 537 at 564 (1997) (describing Amnesty International as transnational).

${ }^{37}$ In at least some circumstances, the author might be better understood as an 'environmental law professor' than as a 'resident of Connecticut'. 
instances, allow for a more refined and closely tailored reflection of an individual's views in relevant decision-making bodies than will be obtained through his or her government. Participation in NGOs also allows individuals to express an intensity of preference that simple voting mechanisms do not permit. ${ }^{38} \mathrm{~A}$ citizen who cares very deeply about ending whaling, for instance, almost certainly will find his or her views better represented in international fora by the Worldwide Fund for Nature than by his or her own government, which has many goals it must simultaneously pursue. At the very least, listening to NGOs offers a cut across the grain of territorial representation which may awaken WTO decision-makers to the complexity and nuances of the issues they face or otherwise provide an additional perspective on what is at stake.

Our growing appreciation of the richness and diversity of 'civil society' reinforces the suggestion that it would be a mistake to think that all interactions among people can be mediated through the narrow channel of national governments. Indeed, one of the cornerstones of the liberal critique of traditional realist international relations theory centres on the assumption that states are the prime (or even the only) actors on the international stage. ${ }^{39}$ A wide variety of transnational forces now operate internationally, NGOs among them. ${ }^{40}$ It would be an error for the WTO not to take cognizance of this transformation or to continue to act as though international affairs were solely a contest among the wills of governments. ${ }^{41}$

The participation of NGOs in WTO debates also can help to compensate for deficient representativeness at the national level. In many countries, weak democratic institutions and other public choice flaws mean that national government policies do not fairly and accurately represent the citizenry's views. In some cases, authoritarian regimes seek to maintain their hold on power with little regard for public opinion. In other countries, leaders are corrupt. And in every country, public choice distortions - special interest manipulation,

38 See Hovenkamp, Legislation, above n. 35 at 75 (providing an example of this problem).

39 Marvin S. Soros, Beyond Sovereignty: The Challenge of Global Policy (1986) 75-119 (describing international actors and including both states as traditional actors and IGOs); Thomas J. Biersteker and Cynthia Wever (eds), State Sovereignty as Social Construct (1996) 444 (describing recent scholarly discussion of state sovereignty); Harold Hongju Koh, 'Why Do Nations Obey International Law', 106 Yale LJ 2599 at 2604-41 (1997) (describing evolving conceptions (of international law) and actors within it).

40 See Barbara J. Bramble and Gareth Porter, 'Non-Governmental Organizations and the Making of US International Environmental Policy' in Andrew Hurrell and Benedict Kingsbury (eds), The International Politics of the Environment (1992) 31 at 313 (describing the role of NGOs in international environmental politics).

${ }^{41}$ See, e.g., G. Richard Shell, 'The Trade Stakeholders Model and Participation by Nonstate Parties in the World Trade Organization', 17 U Pa J Int'l Econ L 359 at 371 (1996) (critiquing 'realist' views of international law that leave trade matters under the control of diplomats and states) [hereinafter Shell, Stakeholders]; Weiss and Gordenker, Global Governance, above n. 25 (reviewing the role of NGOs in a broadened concept of international law). 
campaign contributions, asymmetries of resources and political activity among interest groups, etc. - cause policies to deviate to some degree from the true will of the people. It may seem ironic to suggest that the WTO, often criticized for its 'democratic deficit', could improve the representativeness of decision-making. ${ }^{42}$ But, in many cases, the WTO offers a potentially more open, transparent, and pluralistic decision-making forum than would be available at the national level. In brief, upgrading the quality of the WTO's political debates - through greater transparency and an organized role for NGOs - may substitute for the lack of liberal democracy in a considerable number of countries around the world.

An inclusive approach to NGOs at the WTO also offers important advances from the perspective of the political economy of trade liberalization. Notably, if environmental groups (especially those in North America) and others who have felt excluded from trade policy-making perceive themselves as included in the process and are given a fair opportunity to shape decisions, they are much less likely to obstruct trade liberalization efforts. ${ }^{43}$ The benefits of a strategy of inclusiveness were demonstrated during the course of the North Atlantic Free Trade Agreement (NAFTA) debate in the USA. Both the Bush and Clinton Administrations worked hard to ensure that environmental groups were briefed regularly, included in the US Trade Representative's advisory groups, and given access to the negotiation process. In the end, a number of environmental groups supported the treaty. ${ }^{44}$

A regularized channel of information that flows up from NGOs to the WTO also would be beneficial, especially insofar as it might strengthen the WTO's decision-making capacity. When decisions require an understanding of policy in areas outside of the WTO's existing zones of expertise, such as in 'trade and environment' cases, the opportunity to tap data, information,

${ }^{42}$ See E.U. Petersmann, Constitutional Functions and Constitutional Problems of International Economic Law (1991) 166-7 (describing democratic deficit in EU GATT participation); Picciotto, Networks, above n. 21 at 1037-8 (discussing democratic deficit in international institutions); E.U. Petersmann, 'National Constitutions, Foreign Trade Policy, and European Community Law', 46 Aussenwirtschaft 197 (1991); Frieder Roessler, 'The Constitutional Function of the Multilateral Trade Order' in M. Hilf and E. U. Petersmann (eds), National Constitution and International Economic Law (1992); Guy de Jonquie'res and Michael Smith, 'EU Farm Chief Rebuked Over Swipe at WTO', Financial Times 4, 5 September 1997 (reporting on EU farm commissioner Franz Fischler's 'suggestion that the WTO lacked democratic accountability').

${ }^{43}$ For a review of the political economy of trade liberalization in the United States, see Daniel C. Esty, 'Environmentalists and Trade Policymaking', in Alan V. Deardorff and Robert M. Stern (eds), Representation of Constituent Interests in the Design and Implementation of US Trade Policies (1997). The difficulty President Clinton faced in getting approval for 'fast track' negotiating authority in 1997 - and especially the opposition of environmentally oriented congressmen - demonstrates the saliency of this political economy argument.

${ }^{44}$ See Frederick M. Abbott, 'Foundation-Building for Western Hemispheric Integration', 17 NW J Int'1 L Bus 900 at 924-6 (1997); John Audley, Green Politics and Global Trade (1997) (reviewing the NGO role in NAFTA); Esty, Greening the GATT, above n. 18 at 27-8 (describing environmental NGOs' approach to NAFTA negotiations). 
studies, option assessments, and views from the NGO community broadens the base of analysis on which decisions rest. ${ }^{45}$ In some realms, such as environmental policy, the high degree of scientific flux and other uncertainties makes the capacity to triangulate on the truth especially valuable. As noted earlier, the more clearly that WTO decisions are recognized to be substantively on the mark - appropriately regulating to avoid market failures in the international economic domain and faithfully advancing goals such as environmental protection - the greater the authoritativeness and legitimacy of the organization.

Non-governmental organizations provide the WTO not only with a mechanism to hear views beyond governmental ones, but also with a means for sharing information about what is happening within the international trading system. Many NGOs are ideally situated to play this dissemination role insofar as they have connections to millions of individuals with whom government officials have no direct method of contact. Explaining what is happening within the trade regime and developing a public appreciation of the work that goes on at the WTO are essential prerequisites for broader public support for trade liberalization in general and for the decisions of the WTO in particular.

Regular communication down to people at the grassroots level through the medium of NGOs promises to go a considerable distance toward dispelling the trading system's image as mysterious, distant, and unresponsive. That which people understand they are less likely to react negatively toward. Regular contact with groups around the world also might help governments to mobilize public opinion in favour of freer trade when it comes time to hold congressional or parliamentary votes on free trade agreements or other trade and investment liberalization efforts. ${ }^{46}$

Non-governmental organizations also provide an additional oversight and audit mechanism. Well-informed citizen groups can act as watchdogs of national governments and report on whether they are fulfilling their obligations under international economic law. With better access to documents and meetings, NGOs also would be in a position to review and critique WTO performance. While this may not seem intuitively attractive to those in

45 The same logic would argue for expanded co-operation between the WTO and other international bodies with substantive expertise, such as the UN Environment Program (UNEP). An argument could also be made that a better answer would be to have the WTO incorporate by reference environmental analyses undertaken elsewhere, such as within UNEP, as GATT Article XV contemplates guidance from the International Monetary Fund on certain issues. This author has, in fact, argued for creation of a Global Environmental Organization that could play this role. See Esty, Geo, above n. 7 at 287. But the strengthening of the international environmental regime necessary to make this approach work does not seem imminent.

${ }^{46}$ See A.M. Clark, 'Non Governmental Organizations and Their Influence on International Society', 48 J Int'l Affairs 504 at 518-21 (1995) (discussing NGO information sharing role); P. Ghils, 'International Civil Society: International Non-Governmental Organizations in the International System', 44 Int'l Sci J 417 (1992). 
Geneva, the value of peer review is now widely appreciated. ${ }^{47}$ It would therefore be in the public interest to have WTO decisions carefully scrutinized and analysed to ensure that, at every turn, preferred policy directions are being selected.

Broader public participation in the WTO with communication both up from NGOs and down through these organizations would yield a stronger, more democratic, and more durable international trading system. A richer 'WTO politics' offers the promise of a more responsive, representative, authoritative, and effective WTO.

\section{Non-governmental competition}

As noted above, the WTO makes many complex and technically difficult decisions. The WTO's in-house expertise becomes severely strained when the Secretariat must untangle trade and environment questions, trade and labour issues, or any number of other matters that overlap from the trade domain into other policy areas. In many of these decisions, the capacity of the WTO to produce good policy outcomes - that contribute to its reputation for authoritativeness and responsiveness - depends on having its deliberations enriched through 'outside' information and multiple policy perspectives. In short, there is great value in considering competing policy options. ${ }^{48}$

The benefits of competition are well established in general economic theory. ${ }^{49}$ Increasingly, the gains from bringing competitive forces to bear in the regulatory domain are being understood. ${ }^{50}$ In the context of the WTO decision-making, this theory could translate into national governments advancing competing visions of international trade policy. But the limits of horizontally arrayed governments as the competitors in the regulatory arena also are being recognized. ${ }^{51}$

${ }^{47}$ The OECD, for example, has benefited considerably from having NGOs participate in many (if not all) of its meetings and workshops. See generally Robert F. Housman, 'Democratizing International Trade Decision-Making', 27 Cornell Int'l LJ 699 at 717-18 (1994) (discussing various ways in which NGOs have been allowed participation in the OECD).

48 The benefits of multiple perspectives which permit triangulation on the truth are especially significant in the environmental realm because the field is marked by particularly dramatic uncertainties and technical complexity. See Esty, Revitalizing, above n. 7 at $578-80$.

49 See, e.g., Samuelson and Nordhaus, Economics, above n. 1 at $136-43$ (discussing the equity and efficiency of competitive markets).

50 See William A. Fischel, 'Fiscal and Environmental Considerations in the Location of Firms in Suburban Communities' in Edwin S. Mills and Wallace E. Oates (eds), Fiscal Zoning and Land Use Controls (1975) 119; Richard L. Revesz, 'Rehabilitating Interstate Competition: Rethinking the "Race to the Bottom" Rationale for Federal Environmental Regulation', 67 NYUL Rev 1210 (1992); W. E. Oates and Robert M. Schwab, 'Economic Competition Among Jurisdictions: Efficiency Enhancing or Distortion Inducing', 35 J Pub Econ 333 (1988); Charles M. Tiebout, 'A Pure Theory of Local Expenditures', 64 J Pol Econ 416 (1956).

${ }^{51}$ See Kirsten A. Engel, 'State Environmental Standard-Setting: Is There a "Race" and is it "To the Bottom"?', 48 Hastings LJ 271 at 297-347 (1997); Joshua D. Sarnoff, 'Overcoming Uncooperative Federalism', 39 Ariz L Rev 205 at 215 (1997); Esty, Revitalizing, above n. 7 at 627-38 (discussing arguments over whether regulatory races to the bottom occur). 
In many realms, governments do not generate serious intellectual competition. This weakness is especially acute when the ability to generate policy alternatives turns on technical capacity. Environmental policy-making, for example, often requires careful problem identification, fate and transport analyses, epidemiological and ecological studies, risk assessment, policy design and options development, and cost-benefit analyses. Not many governments in the world are positioned to carry out this type of analytically intensive activity. Hence, few serve as serious idea generators and thus policy competitors at the WTO.

There are other reasons to be sceptical about achieving better international policies through intergovernmental regulatory competition. Notably, international bodies often have narrow mandates and therefore narrowly focused secretariats and national representatives. The WTO's mission, for example, is trade liberalization. When trade policies overlap into other domains, the tendency is for all those at the WTO - both staff and those representing capitals - to see the problem through a trade lens. Thus, debates over issues such as 'trade and the environment' go forward within a limited band of viewpoints. Too often both the international civil servants and government officials are happy to ignore issues that fall beyond their bailiwick. It is thus helpful, if not essential, that NGOs, drawing on a wider array of perspectives and expertise, be available to prod governments into paying attention to 'peripheral' - but not unimportant - issues such as protection of the environment. ${ }^{52}$

In many cases, NGOs are better positioned to serve as intellectual competitors than governments. These organizations often have the requisite analytic and technical skills to delve into the matters at hand. Their success and rewards derive from being recognized as contributors to improved policy outcomes. ${ }^{53}$ In addition, NGOs frequently are more nimble than governments in spotting new issues and shifting their resources quickly in response. In an ideal world, governments might be expected to re-evaluate their policies regularly and then be positioned to bring fresh thinking to the fore, making a prominent NGO role unnecessary. But in the real world, governmental

52 See Elizabeth Dowdeswell and Steve Charnovitz, 'Globalization, Trade, and Interdependence' in Marian Chertow and Daniel Esty (eds), Thinking Ecologically: The Next Generation of Environmental Policy (1997) 91 at 99; see also Dunoff, Trade And, above n. 14 at 763-4 (discussing the limitations of the WTO in addressing 'trade and' issues).

${ }^{53}$ In this sense, market forces discipline NGOs. Groups perceived to be doing a poor job (and not undergirding their environmental campaigning with rigorous analysis) suffered reduced contributions and forced cut-backs in staffing, while those who were perceived as valuable contributors to current debates found their membership and support surging. The contrast between Greenpeace, which recently was forced to close ten of its US regional offices as a result of a budget shortfall, see Greenpeace Protest Group Slashing US Budget, Staff, Wash Post, 10 August 1997 at A4, and the Environmental Defense Fund, which has seen its membership rise six-fold over the past ten years, is instructive. See Environmental Defense Fund, Memo on Membership Growth 1967-1996 (on file with author). 
inertia is overwhelming. Thus, regulatory competition from outside the governmental domain becomes essential to a sound policy-making process.

The logic of horizontal competition - between governments and NGOs at the WTO - builds on the basic economic understanding that welfare gains can be achieved by having competing options available. Political theory suggests, similarly, that vertical competition among levels of government - local, state, national, and global - will produce benefits. Specifically, the dispersion of power across various levels of authority provides useful 'checks and balances' on mistakes and abuses of power. ${ }^{54}$ An NGO-enriched WTO decision process would offer better competition for national governments in the search for optimal policies. To the extent that national trade debates disregard issues or useful perspectives, a more robust WTO political process would ensure a full airing of the issues and options.

If national debates prove to be systematically limited, ${ }^{55}$ WTO discussions, fueled by the intellectual competition of NGO participation, might well take on increased significance over time. The end result would be an international trading system that has greater legitimacy and effectiveness as well as broader political and public support.

\section{Fears about the role of non-governmental organizations at the World Trade Organization}

Despite these benefits, many in the trade community continue to resist NGO involvement at the WTO. The desire to exclude NGOs from a formal role in the international trade regime can be traced to a number of concerns. In brief, those who would exclude NGOs from international trade policy-making believe that an increased presence for environmental groups and other non-governmental entities within the halls of the WTO headquarters on Lake Geneva would distort rather than improve the decision-making process. ${ }^{56}$ While the concerns about NGOs at the WTO are real, they are not unanswerable. Indeed, in recent years, many of the fears expressed above have

${ }^{54}$ See 5 Writings of James Madison 27 [G. Hunt (ed.) 1901]; Akhil R. Amar, 'A Neo-Federalist View of Article III: Separating the Two Tiers of Federal Jurisdiction', 65 BUL Rev 205 at 247 (1985) (arguing a strong federal government represents a bulkwark 'against overweening state governments'); Akhil R. Amar, 'Of Sovereignty and Federalism', 96 Yale LJ 1425 at 1444-65 (1987) (outlining the Framers' theories of competition in government).

${ }^{55}$ See the 'public choice' discussion in Section A, above n. 35 and accompanying text, for a review of why national trade policy-making might be systematically sub-optimal.

${ }^{56}$ Curiously, there is little academic literature arguing against a broader role for NGOs at the WTO. Government officials seem to be the leading critics of expanded NGO participation. For the best arguments against participation, see Bhagawati and Srinivasan, Trade and Environment at 195; Nichols, Realism, above n. 25 (explaining potential problems of NGO participation at the WTO); William Diebold, 'Reflections on the International Trade Organization', $14 \mathrm{~N}$ Ill UL Rev 335 (1994) (discussing major business groups refusing to follow ITO charter agreements); William M. Reichert, 'Note, Resolving the Trade and Environment Conflict: The WTO and NGO Consultative Relations', 2 Minn J Global Trade 219 at 230 (1996) (cataloguing problems with NGO participation) [hereinafter Reichert, Resolving]. 
been narrowed or even put to rest. ${ }^{57}$ Steve Charnovitz demonstrates, moreover, that NGOs have a long history of involvement in international economic relations. ${ }^{58}$ Thus, the current limited role at the WTO represents an historical anomaly and a low point in an evolutionary cycle. ${ }^{59}$

\section{Special interest manipulation}

Whenever lobbying of a decision-making body is permitted, there exists a risk that certain interests will exert disproportionate influence. ${ }^{60}$ Some analysts suggest that interest group participation slows decision-making processes and leads to inefficient results. ${ }^{61}$ Thus, critics of a broader role for NGOs at the WTO worry that the presence of environmental groups or of other organizations lobbying WTO officials or governmental representatives at the WTO will result in distorted policy outcomes. ${ }^{62}$ One commentator, Peter Spiro, warns that NGO leaders, armed with fattened bank accounts and with the leverage of large but docile memberships, have emerged as a new class of modern day potentates. ${ }^{63}$

A more refined version of the special-interest-domination fear stems from governments' need to trade off competing domestic interests to strike agreements that liberalize trade. In many cases, trade officials must give up the particularized interests of certain industries or groups - especially inefficient industries hiding behind tariff barriers or other protectionist walls - to obtain benefits for the general public they represent. ${ }^{64}$ It is often easier to go behind closed doors to cut these deals. Indeed, severe 'public choice' problems,

57 See, e.g., Charnovitz, Participation, above n. 9 (rebutting the arguments against NGO participation); Shell, Stakeholders, above n. 41 (offering a model for NGO participation at the WTO and refuting various concerns about such a role); Esty, Why NGOs, above n. 25 at 4-7.

${ }^{58}$ See Charnovitz, Two Centuries, above n. 8. As Charnovitz points out, NGOs played a major role in leading the world toward the abolition of slavery in the 19th century. They have also been strong advocates for peace and for worker rights for more than a hundred years. NGOs have had a longstanding involvement in international trade policy-making, including promoting free-trade and the end of the British corn tariffs in the mid-nineteenth century. See ibid. at 189-95.

59 The post-Second World War international leaders who crafted the GATT, the forerunner of today's World Trade Organization, clearly anticipated a significant role for NGOs. In fact, Sir Eric Wyndham White, the first head of the GATT, advanced a quite specific NGO agenda. Specifically, he proposed that the International Trade Organization (ITO): (1) draw up a list of NGOs to be given consultative status; (2) invite NGO observers to ITO conferences and allow them to propose agenda items and to speak; (3) consult with NGOs with competence in particular fields of activity related to ITO efforts; and (4) appoint an advisory committee of NGO representatives. See Steve Charnovitz and John Wickham, 'Non-Governmental Organizations and the Original International Trade Regime', J World Trade 111 at 117-18 (1995); Charnovitz, Participation, above n. 9 at $338-9$.

${ }^{60}$ See e.g., Anthony Downs, An Economic Theory of Democracy (1957); Olson, Logic, above n. 3; James M. Buchanan and Gordon Tullock, The Calculus of Consent (1971); Elmer E. Schattschneider, Politics, Pressures and the Tariff (1935).

${ }^{61}$ See Mancur Olson, The Rise and Decline of Nations (1982) 41-5; Nichols, Realism, above n. 22 at 861-6.

${ }^{62}$ Nichols, Realism, above n. 25 at 860-66.

${ }^{63}$ See Spiro, Potentates, above n. 34 at 963.

${ }^{64}$ See Esty, Why NGOs, above n. 25 at 4-5; Jackson, Reflections, above n. 7 at 511. 
arising from the visibility of the gains to narrow groups from closed markets and from the relative invisibility of the diffuse benefits of open markets, are endemic in the trade domain. ${ }^{65}$ Many trade experts fear that an expanded role for NGOs at the WTO therefore would exacerbate the tendency to hear protectionist voices, making the pursuit of trade liberalization more difficult.

Free traders' concerns are heightened by a perception that many NGOs are unsympathetic to trade liberalization efforts and perhaps even protectionist. ${ }^{66}$ These fears have some basis in fact; a number of environmental groups and many labour unions are fundamentally opposed to free trade. ${ }^{67}$ Almost by definition, the groups that historically have not had entree to the WTO and now want access are not trade-oriented. Thus, they bring to trade debates no special commitment to open markets and, in most cases, their core interests centre on some other agenda such as environmental protection.

The fear of NGOs acting as special interests, and manipulating WTO outcomes is, however, overblown. Special interests, representing (often protectionist!) business entities, already inhabit the WTO. Adding additional NGO perspectives, likely would counteract and blunt the influence of existing interests and therefore reduce, not increase, the risk of special-interest-driven policy outcomes. Indeed, the presence of a more diverse set of interests within the WTO decision process largely would be self-policing as the various groups could monitor each other, exert countervailing pressures, and generally diminish the prospect of the 'capture' of the WTO by narrow interest groups. ${ }^{68}$

${ }^{65}$ Groups representing special interests that have a great deal at stake in trade policy often will invest considerable resources to protect their positions. On the other hand, the general public, which benefits broadly but not deeply from freer trade, is much harder to activate politically. Thus, there exists a significant asymmetry between those who benefit from open markets (a diffuse and not well organized public) and those who seek protectionism (concentrated groups which are often easier to mobilize). See Philip M. Nichols, 'Extension of Standing in the World Trade Organization Disputes to Non Governmental Entities', 17 U Pa J Int'l Econ L 295 at 319-20 (1996) [hereinafter Nichols, Extension]; Nichols, Realism, above n. 25 at 860; E.U. Petersmann, 'Settlement of International and National Trade Disputes Through the GATT: The Case of Antidumping Law' in E. U. Petersmann and G. Jaenicke (eds), Adjudication of International Trade Disputes in International and National Economic Law (1992); see also Alan V. Deardorff and Robert M. Stern, 'An Overview of the Modeling of Choices and Consequences of US Trade Policies' in Alan V. Deardorff and Robert M. Stern (eds), Representation of Constituent Interests in the Design and Implementation of US Trade Policies (1997).

${ }^{66}$ See Esty, Why NGOs, above n. 25 at 5; Reichert, Resolving, above n. 56 at 220-1.

${ }^{67}$ See Daniel C. Esty, Greening the GATT, above n. 18 at 27-29; Reichert, Resolving, above n. 56 at 221 .

${ }^{68}$ See Arvind Subramanian, 'Trade Measures for Environment: A Nearly Empty Box', 15 World Economy 135 (1992) (reviewing the risk of capture of the trading system); Spiro, Potentates, above n. 34 at $962,962-8$ (concluding that institutionalizing the role of NGOs could work to improve international institutional decision-making while avoiding the risk of interest group capture of the global marketplace'); Kevin Stair and Peter Taylor, 'Nongovernmental Organizations and the Legal Protection of the Ocean: A Case Study' in Andrew Hurrel and Benedict Kingsbury (eds), The International Politics of the Environment (1992) 110 at 134 (discussing general benefits to international law of NGO participation). 
The suggestion, furthermore, that more open processes would make achieving trade liberalization harder because governments could not cut deals rests on two faulty assumptions. First, it is by no means clear that the current non-transparent negotiating style promotes freer trade. To the contrary, many protectionist results have emerged from the WTO and from the General Agreement on Tariffs and Trade (GATT) before it. ${ }^{69}$ Second, public choice distortions generally become more severe not less so, when decisions are made out of public view. ${ }^{70}$ Transparent decision processes, in which positions are openly disclosed and debated, represent a powerful force in support of outcomes that track the public interest. ${ }^{71}$

The observation that many of the groups that seek access to the WTO are closet, if not overt, protectionists may be true, but it offers no real argument for closed door meetings. World Trade Organization secrecy only serves to heighten anxiety about trade liberalization. Many environmental groups, in particular, are highly sensitive to process issues - and their opposition to freer trade might well be more muted if they better understood how trade policy decisions are made.

2. The World Trade Organization is an intergovernmental body

A second major argument against an expanded NGO role in the international trading regime derives from the belief that the WTO should be an intergovernmental body. According to this view, the trade policy process works best when governments can speak clearly to each other without a cacophony of other voices. As Philip Nichols suggests, it can be confusing to have domestic constituencies opposing the positions of the governments that are supposed to represent those constituencies. ${ }^{72}$ Another strand of this argument recoils at the prospect of NGOs getting two bites at the apple. Why, critics ask, should NGOs be able to lobby both at the national level in the debate over their government's WTO approach and again at the WTO itself?

Other observers argue that the essence of international affairs is relations among sovereign states. To the extent that international bodies must deal with other actors as well, their decision processes become murky and the foundation for their legitimacy uncertain. ${ }^{73}$ While this state-centric view of

${ }^{69}$ The Multi-Fiber Agreement and dispute settlements that codify Voluntary Restraint Agreements are the examples of this tendency. See, e.g., James Bovard, The Fair Trade Fraud (1991).

${ }^{70}$ To ensure further transparency, the WTO should develop procedures to require the disclosure of all lobbying activities and to prohibit its staff from accepting gratuities from those with interests in the outcome of their work. See Esty, Why NGOs, above n. 25 at 6.

${ }^{71}$ See, e.g., J. Oloka-Onyango, 'Beyond the Rhetoric: Reinvigorating the Struggle for Economic and Social Rights in Africa', 26 Cal W Int'l LJ 1, 71 (1995) ('In order to have honest agencies that serve the public interest, transparency is crucial ... ').

${ }^{72}$ See Nichols, Extension, above n. 65 at 308-9; see also Esty, Why NGOs, above n. 25 at 5.

${ }^{73}$ See Esty, Why NGOs, above n. 25 at 5; Nichols, Extension, above n. 65 at 308; Nichols, Realism, above n. 25 at $874-8$ (arguing for 'institutionalism' as a more refined version of realist international relations theory). But see Shell, Stakeholder, above n. 41 at 371-9 (criticizing Nichols' narrow institutionalist view of international relations). 
the world might be critiqued as passé, ${ }^{74}$ it is a mistake to gainsay the important role states play in international relations ${ }^{75}$ or to deny that the presence of NGOs complicates state-to-state relations.

The argument that the WTO is meant to be an intergovernmental body is both superficially true and beside the point. Giving NGOs a voice at the WTO, and more importantly, the opportunity to observe WTO debate and dispute settlement proceedings, does not preclude governments from discussing some issues behind closed doors. The WTO need not be a purely state-to-state institution. ${ }^{76}$ To suggest, moreover, that all NGO influence should occur at the national level misunderstands the complexity of the modern world. As noted earlier, some NGOs are international in scope. Telling these groups that they must exert influence only at the national level is to deprive them of their transnational essence. ${ }^{77}$ In addition, some political debates are conducted better at the international level because the underlying issues involve questions of global governance. ${ }^{78}$ Institutions, such as the WTO, that play a role in setting and enforcing the rules of international behaviour, will be strengthened to the extent that they encourage a full and rich debate over the directions to be taken. ${ }^{79}$

3. Unrepresentativeness of non-governmental organizations

A third set of concerns about the role of NGOs in the WTO relates to their representativeness and accountability. ${ }^{80}$ In fact, it may well be difficult to ascertain how many and which people a particular group represents.

${ }^{74}$ See Cameron and Ramsay, Participation, above n. 27 at 11; Reichert, Resolving, above n. 56 at 221-3; see also Gordenker and Weiss, Pluralizing, above n. 27 at 34; David Scott Rubinton, 'Toward a Recognition of the Rights of Non-States in International Environmental Law', 9 Pace Env L Rev 475 at 487-91 (describing the movement from a state-centric approach in the environmental realm).

75 See Ian Brownlie, Principles of Public International Law (1990) 287-8 (discussing traditional sovereignty and equality of states in the international system); Gordenker and Weiss, Pluralizing, above n. 27 at 34; Anne-Marie Slaughter, 'The Real New World Order', 76 Foreign Affairs 183 (1997); Nichols, Realism, above n. 25 at 877.

${ }^{76}$ Even institutionalist critics of an expanded role for NGOs at the WTO acknowledge that hybrid institutions - in which governments share the stage with non-governmental entities - are not only conceivable but sometimes even useful. See Nichols, Realism, above n. 25 at 877-8.

77 Amnesty International is not a British organization but a worldwide one. The World Wildlife Fund - as its very name suggests - is an international organization made up of representatives from more than a 100 countries. See generally Gordenker and Weiss, Pluralizing, above n. 727 at 27-8; Michael H. Posner and Candy Whittome, 'The Status of Human Rights NGOs', 25 Colum Hum R L Rev 269 at $270-2$ (1994) (examining human rights NGOs).

${ }^{78}$ See Steve Charnovitz, 'A Critical Guide to the WTO's Report on Trade and Environment', 14 Ariz J Int'l Comp L 341 at 367 (1997); Tarlock, Role, above n. 24 (describing the complicated nature of transboundary environmental problems and the benefit of international debate over responses).

${ }^{79}$ As Part II above explains in detail, there are a number of reasons to believe that governments systematically do not bring forward all of the perspectives and arguments which should be considered in setting the course for international bodies such as the WTO.

${ }^{80}$ See Spiro, Potentates, above n. 34 at 963; Tarlock, Role, above n. 24 at 75. 
Non-governmental organizations with ostensibly similar constituencies might present conflicting view points. This raises a number of questions. To whom should officials in international bodies listen? How do we know if the things NGOs say are true? What disciplines do NGOs face which ensure their responsible behaviour? Would increased NGO participation in debates at the WTO not give more weight to views from the developed north as opposed to those of the developing south? ${ }^{81}$

It is no doubt true that certain perspectives (especially those backed by money) will be represented more fully if the WTO were opened up to NGOs. Concerns about the representativeness of NGOs should not, however, be taken too seriously. World Trade Organization decision-makers more often are swayed by the quality of arguments made than by the quantity of noise they hear from a particular quarter. Just as national officials learn over time which groups represent important perspectives and will provide useful information, so too would officials of the WTO. In the international domain, as in national political discourse, the credibility and weight given to NGO positions would vary with the political mobilization potential of the group and the quality of its past contributions to public dialogues. Moreover, fears of a North-South imbalance in the participation of NGOs in Geneva already have begun to subside as the developing world gains new groups and advances in information technology make it possible to participate in WTO decision-making from a great distance at ever lower costs. ${ }^{82}$ Indeed, the internet and e-mail have dramatically lowered the cost of staying on top of WTO activities.

\section{Practicalities of non-governmental organization participation}

Other worries centre on the practical difficulties of credentialling NGOs and controlling their activities within the international trading system. Who would determine which groups actually constitute NGOs? How would the right to speak be allocated? Would not the already limited time available to governments in open meetings be further diluted? Other observers worry that the presence of NGOs in the room at WTO meetings would chill candour. Governments, they fear, would resist exposing their underlying policies to greater scrutiny and perhaps criticism at home, which are inevitable byproducts of more transparent decision processes that include NGOs. ${ }^{83}$

${ }^{81}$ See Nichols, Extension, above n. 65 at 318-19; Charnovitz, Participation, above n. 9 at 343; see also Reichart, Resolving, above n 56 at 244-6 (discussing worries about NGOs being biased toward Northern interests).

${ }^{82}$ See Gordenker and Weiss, Pluralizing, above n. 27 at 25; see also Richard H. Steinberg, 'TradeEnvironment Negotiations in the EU, NAFTA, and WTO: Regional Trajectories of Rule Development', 91 Am J Int'l Law 231 (1997) (arguing that the power of developed country 'green' interests will be relatively low at the WTO because their influence must be spread widely).

${ }^{83}$ See Nichols, Extension, above n. 65 at 319; see also Jackson, Reflections, above n. 7 at 517 (noting the tendency of international organizations to prefer secrecy). But see Charnovitz, Participation, above n. 9 at 343-5 (arguing that the WTO should not seek to maintain anonymity). 
These practical concerns can be addressed. Models for managing the participation of NGOs in international meetings abound. ${ }^{84}$ In fact, as the WTO matures and evolves as a governance mechanism, it needs a more fully developed administrative law structure that spells out rules and procedures for its decision processes.

Not only is the current exclusion of NGOs from substantive participation in the WTO historically anomalous from the perspective of the trade domain, it is entirely inconsistent with the relationship between NGOs and intergovernmental organizations in other realms. ${ }^{85}$ Even within the international economic domain, the WTO lags behind other bodies. The World Bank, for example, has developed a series of procedures to permit NGOs access to its meetings and decision processes. ${ }^{86}$ Likewise, the Organization for Economic Co-operation and Development has broadened its outreach considerably to NGOs in recent years.

In sum, there are practical issues to overcome if NGOs are to participate effectively, efficiently, and appropriately in WTO activities. But fears of a cacophony of voices need not take on a magnified importance, nor should worries about the dilution of governmental influence be exaggerated.$^{87}$

\section{A PRACTICAL PROPOSAL FOR CO-OPERATION AND COMPETITION}

By arguing for an expanded role for NGOs at the WTO - to promote connections from the organization to distant publics and to expand the data and

${ }^{84}$ See Esty, Why NGOs, above n. 25; Charnovitz, Two Centuries, above n. 8.

${ }^{85}$ Non-governmental organizations played a major role in the UN Conference on Environment and Development, including the many preparatory meetings that led up to the June 1992 Earth Summit in Rio de Janeiro. More recent UN conferences - the 1994 Cairo Population Conference, the 1995 Beijing Woman's Conference, and the 1996 Copenhagen Conference on Human Habitats - similarly have involved thousands of NGOs. See, e.g., Charnovitz, Two Centuries, above n. 8 at 266; Charnovitz, Participation, above n. 9 at 335-6, 336 n. 25; Wendy Shoerer, 'Note, NonGovernmental Organizations and Global Activism: Legal and Informal Approaches', 4 Ind J Global Leg Stud 537, 569 n. 76 (1997). But see Nichols, Realism, above n. 25 at 856-7 (arguing against opening the WTO to NGOs and noting that just because every other international body 'jumps off a roof' the WTO should not follow). Note, however, that Nichols, while dismissing Charnovitz's comparisons, makes no effort to explain what makes the WTO unique or especially unsuited to NGO participation.

86 See Paul Nelson, The World Bank and Non-Governmental Organizations (1995); Barbara J. Bramble and Gareth Porter, 'Non-Governmental Organizations and the Making of US International Environmental Policy', C990 Ali-Aba 407, 415-21 (1995); David Reed, 'The Global Environmental Facility and Non-Governmental Organizations', 9 Am U J Int'l L Policy 191 at 202-4 (1993); Tarlock, Role, above n. 24 at 71-2.

${ }^{87}$ Of course, designing working mechanisms for NGO participation at the WTO will require some accommodation on the part of NGOs. If NGOs are to be effective in their roles as co-operators and competitors with governments, they must also change how they carry out their business. In particular, NGOs will need to sharpen their educational activities to ensure that they are capable of playing the information flow role. And if these groups are to succeed as competitors to government, they must become more analytically rigorous. For a discussion of the variance in strength and quality of NGOs, see Esty, Why NGOs, above n. 25 at 6; Reichert, Resolving, above n. 56 at 239-41. 
analysis which underlie WTO decisions, especially when trade policy decisions spill over into other realms such as the environmental domain - I do not mean to suggest that all NGO activity at the WTO would be welcome or helpful. It is important that access permitted in the name of transparency or public participation not devolve into manipulation of the international trade policy-making process by special interests.

Creating the right sort of NGO role is not a trivial matter. In establishing the parameters for non-governmental participation in the international trading system, it is important to distinguish, at the outset, between: (1) WTO adjudicatory processes, (2) WTO legislative activities, and (3) trade negotiations per se. The logic for non-governmental participation, the exposure to the risk of special interest distortions, and the difficulty of managing the practicalities of NGO involvement varies considerably across these different activities.

\section{World Trade Organization dispute resolution}

The arguments for allowing NGO observation of and limited participation in the WTO dispute settlement process are overwhelming. ${ }^{88}$ Permitting NGOs to watch the proceedings when parties give evidence to dispute panels and to have access to written submissions would go a considerable distance toward dispelling fears about the unexplained 'black box' that hides WTO decisions emanating from the shores of Lake Geneva.

The Uruguay Round Dispute Settlement Understanding ${ }^{89}$ moves the WTO dispute resolution process solidly in the direction of more formal adjudication. Opening the proceedings to non-governmental observers would be a useful additional step - at no risk to the integrity of the process. Indeed, it is hard to imagine how the presence of NGOs would distort the outcome of the panel process, except to the extent that governments could not say one thing to the panelists and something else publicly. ${ }^{90}$

${ }^{88}$ The opening up of the dispute settlement process to non-governmental entities has already begun. Many governments, for example, employ private attorneys to help them prepare their briefs and arguments. See WTO Report of the Appellate Body European Communities-Regime for the Importation, Sale and Distribution of Bananas, AB-1997-3, WT/DS27/AB/R (9 September 1997) at 11 (noting the extensive role played by 'private counsel'). Jeffrey Dunoff argues that many trade disputes (e.g., the recent Kodak-Fuji film dispute and the US-Venezuela reformulated gasoline case) are better understood as disputes between private parties. This reality further weakens the argument for excluding non-governmental actors. See Jeffrey L. Dunoff, The Death of the Trade Regime (1998) at 64-8.

89 See General Agreement on Tariffs and Trade - Multilateral Trade Negotiations (The Uruguay Round): Understanding on Rules and Procedures Governing the Settlement of Disputes (15 December 1993) reprinted in 33 ILM 112 (1994) (setting up new procedures including an appellate process).

90 To the extent that governments want to 'negotiate' solutions to disputes, they would, of course, continue to be free to do so. That the dispute process would not be available as a forum for such discussions is of little consequence. All of the governments at the WTO know how to set up intergovernmental meetings. 
The practicalities of assigning seats in the audience for panel hearings represents an inconsequential administrative burden. Limited space might be allocated by lottery or given in turn to credentialed NGOs. ${ }^{91}$ Any group that creates a disruption can be, and should be, barred from future WTO access.

Allowing NGOs to make submissions to the panels also would be constructive. In many cases, WTO dispute panels would benefit from having outside views available. In cases where the scope of a case goes beyond the boundaries of trade law, e.g., environmental questions or other scientific and technical issues are at play, non-governmental view points might be especially illuminating. Not only would NGO submissions thus be available to provide competing data, science, risk or cost-benefit analyses, and policy conclusions which would broaden the information base on which the panelist must rely, but the NGO participation in the decision process also would help to legitimize the panel's decision and broaden public acceptance of the outcome.

If rules prohibiting ex parte contacts with panel members are in place and all submissions must be in writing and open to scrutiny and rebuttal, the risk of manipulation by special interests is virtually non-existent. World Trade Organization decisions would rely on NGO submissions only to the extent that the arguments and information presented assists the members of the dispute panel with their analyses. The administrative burden would be easy to manage through page limits, form requirements, and the provision of legal assistants to the panelists in any case in which the outside submissions were large in number. ${ }^{92}$

\section{World Trade Organization legislative functions}

Defining the bounds of NGO participation in WTO policy development, review, and rule-making activities would require a somewhat more complicated structure. With respect to formal meetings such as the General Council or to the sessions of subgroups like the Committee on Trade and Environment (CTE), allowing NGO observers might broaden public understanding of the work of the WTO. If NGOs were permitted to watch the proceedings, they could, with their networks of contacts, help to disseminate information on policy issues under discussion. If they were given (carefully circumscribed) opportunities to present material, they also could add to the knowledge base of the WTO Secretariat and of the government officials participating in the work of the WTO.

\footnotetext{
${ }^{91}$ I would envision a credentialing process that gives WTO access to any non-governmental group that agrees to abide by the WTO's rules and procedures.

${ }_{92}$ Many models exist for such submissions, including the amicus curiae (friend of the court) procedures under US law. See Sup Ct R 37.
} 
The risk of outcome manipulation by special interests is not especially serious in the course of formal meetings. The fact that information must be presented publicly, records are kept on what is said, and any material offered is open to scrutiny and debate minimizes the risk of inappropriate influence being exerted.

The real danger of special interest distortion comes from informal contacts and private meetings. Of course, lobbying by special interests of the WTO staff or national representatives occurs today. Establishing formal roles for NGO participation in WTO activities would not add to, and might even diminish, the risk of inappropriate pressure being brought to bear. In particular, if formal procedures for the airing of NGO views were in place, WTO officials could steer those seeking to meet with them privately toward these public sessions where attempts to win special favours would be harder to execute.

The opening of formal WTO meetings to NGOs also might present an opportunity to introduce lobbying disclosure requirements that mandate public reporting of all informal contacts between NGOs (including business as well as public interest groups) and WTO officials. At the same time, rules on gifts to officials also might be put in place. As the WTO matures into a more important element of our global governance structure, it is reasonable to expect that it will have to adopt operating procedures which improve the transparency and perceived fairness of its decision processes.

In any case, the salient fact is that excluding NGOs from the WTO does not shelter the organization from special interest manipulation. Likewise, establishing a formal role for NGOs within the WTO creates no additional risk of protectionist results emerging from the organization's decision processes. Thus, the argument that excluding NGOs creates a useful 'buffer' between decision-makers and special interest groups has no foundation whatsoever. ${ }^{93}$

\section{Trade negotiations}

Actual trade negotiations remain fundamentally a government-to-government bargaining process and thus present the strongest case for a measure of secrecy. Given the complexity of making trade deals and the added degree of difficulty 'open' negotiations would entail, WTO mandates on NGO involvement in negotiating sessions would be misguided. Whether national authorities want to share their negotiating positions and strategies with nongovernmental entities must be left to each country individually. While many countries have found it useful to consult with interested parties in the course 
of negotiations, ${ }^{94}$ whether and how such discussions take place should remain a matter of national policy.

\section{CONCLUSION}

The WTO is emerging as an institution of considerable importance in the international economic realm. Managing the flow of trade, setting the boundaries for appropriate behaviour in international commercial transactions, and guarding the global economic system against market failures represents a significant responsibility.

If the WTO is to discharge its obligations in a way that builds legitimacy and respect and that minimizes market failures, it must take more seriously the opportunity represented by an active role for NGOs. Indeed, if the organization is to produce consistently 'correct' answers to the policy problems that it is asked to address, it must have input from NGOs. For the decisions that emerge from this body to be viewed as representative, authoritative, and fair, the WTO must provide mechanisms for expanded public participation in its decision-making processes.

In a co-operative role, NGOs can facilitate a flow of information to and from decentralized citizens and thereby diffuse concerns about the WTO's democratic deficit. In addition, by competing with governments in the WTO analytic realm, NGOs can help to ensure that the WTO makes well-informed and carefully considered decisions. While the risk of special interest manipulation of WTO decision-making is real and should be taken seriously, excluding NGOs from a formal role at the WTO does nothing to address the danger. Disclosure requirements and rules that spell out when and where lobbying is appropriate are the answer to this problem. In sum, a WTO that includes NGOs will be stronger, more durable, and better able to perform its essential functions.

94 For example, the US Trade Act of 1974 provides mechanisms for consultation in trade negotiations. See Oscar C. Sattinger, 21 Am Jur 2d Customs Duties and Import Regulations $\ 20$ (1981); see also Jonathan I. Miller, 'Comment, Prospects for Satisfactory Dispute Resolution of Private Commercial Disputes Under the North American Free Trade Agreement', 21 Pepp L Rev 1313 at 1313 n. 23 (1994) (discussing the extensive consultations with the private sector during NAFTA negotiations). 